\title{
TEOLOGI CALVIN DAN PEMERINTAH
}

\author{
Ali Salim
}

\begin{abstract}
Abstrak: John Calvin bukan hanya seorang teolog belaka, tetapi ia berperan besar dalam mengedit undang-undang dan pemikirannya sangat besar pengaruhnya dalam dunia politik. Dalam rangka menyambut hari Reformasi ke-500, artikel ini akan membahas beberapa pemikiran John Calvin tentang negara dan pemerintahan.
\end{abstract}

Kata-kata Kunci: John Calvin, negara, pemerintah, reformed

Abstract: John Calvin is not only a theologian, he is also a legislator and his idea predispose politics. In order to celebrate 500 years of reformation, this article try to address some of John Calvin views about state and government.

Keywords: John Calvin, state, government, reformed

\section{PENDAHULUAN}

Abraham Kuyper, di dalam bukunya Ceramah-Ceramah Mengenai Calvinisme mengatakan bahwa, "Sebab sesungguhnya tanpa dosa pasti tidak akan ada tatanan penguasa dan negara ... bahwa Allah telah membentuk orang-orang memerintah, karena alasan dosa."1, dan "Tak seorang pun mempunyai hak untuk memerintah atas orang lain, dan jika hal ini diizinkan maka hak seperti itu akan segera menjadi hak bagi mereka yang terkuat."2 Kedua pernyataan ini mengatakan bahwa pemerintahan muncul karena akibat dosa dan manusia tidak mempunyai hak untuk memerintah manusia lain. Karena hal ini ditulis di dalam buku

\footnotetext{
${ }^{1}$ Abraham Kuyper, Ceramah-Ceramah Mengenai Calvinisme (Surabaya: Penerbit Momentum, 2005), 90.

${ }^{2}$ Ibid., 92 .
} 
berjudul Ceramah-Ceramah Mengenai Calvinisme maka pembaca dapat menyimpulkan bahwa hal ini adalah pemikiran John Calvin, sang reformator. Namun apakah John Calvin berpendapat bahwa pemerintah dibentuk karena dosa? Calvin juga menulis banyak hal tentang negara, pemerintahan, hak dan kewajiban pemerintah, yang kemudian menjadi dasar bagi negara-negara penganut Protestan. ${ }^{3}$ Dalam rangka menyambut reformasi, artikel ini membahas sedikit pemikiran John Calvin tentang negara dan pemerintahan.

\section{AUGUSTINUS}

David W. Hall mengatakan bahwa pemikiran John Calvin berasal dari para pemikir besar sebelumnya dan salah satunya adalah bapak gereja Augustinus dari Hippo (354-430). ${ }^{4}$ Berbicara mengenai politik dan pemerintahan Augustinus maka tidak akan pernah terlepas dari pandangan Augustinus yang ditulis di dalam bukunya De Civitatis Dei. Buku ini ditulis sebagai apologia untuk orang-orang Roma yang menuduh orang-orang Kristen di kota Roma yang menyebabkan keruntuhan kota Roma karena mereka tidak lagi menyembah dewa-dewa yang melindungi kekaisaran Roma. Augustinus berusaha menjelaskan bahwa kejatuhan kota Roma adalah karena kebobrokan moral yang terjadi di kota Roma.

Menurut Augustinus, pemerintahan manusia berasal dari akibat kejatuhan dalam dosa dan bukan dalam tatanan ciptaan (creation order). ${ }^{5}$ Karena itu, Augustinus merasa perlu adanya pemerintah sebagai suatu alat pengendali masyarakat. ${ }^{6}$ Baik Augustinus maupun kemudian Calvin beranggapan bahwa berdirinya kerajaan dan pemerintahan adalah atas dasar providensia

\footnotetext{
${ }^{3}$ David W. Hall, Calvin di Ranah Publik (Surabaya: Penerbit Momentum, 2011), 3.

${ }^{4}$ Ibid., 4.

${ }^{5}$ Ibid., 7.

${ }^{6}$ Ibid., 5.
} 
Tuhan. Tidak ada pemerintah yang berasal di luar kedaulatan Tuhan. ${ }^{7}$

\section{THOMAS AQUINAS}

Berbeda dari Augustinus, Thomas Aquinas mengatakan bahwa negara tidak muncul karena disebabkan oleh dosa. Ia memberikan dua alasan untuk mendukung pendapatnya. ${ }^{8}$ Yang pertama yaitu manusia adalah makhluk sosial. Sekalipun manusia tidak jatuh ke dalam dosa maka akan ada salah satu bentuk pemerintahan. Yang kedua, adanya orang yang bakatnya melebihi orang lain menyebabkan orang tersebut wajib menggunakan bakatnya untuk kepentingan umum dengan menjadi penguasa.

Thomas Aquinas juga berbicara tentang pemberontakan kepada pemerintah. Aquinas mengatakan bahwa memberontak adalah dosa namun memberontak terhadap penguasa yang tiranis dan kejam atau membatasi kekuasaannya diperbolehkan.9 Alasannya adalah penguasa yang tiran mementingkan kepentingan pribadinya dan bukan kepentingan bersama. Penggulingan kekuasaan pemerintah diperbolehkan selama tidak membuat dampak kekacauan yang lebih besar dan tidak dengan kekerasan. ${ }^{10}$

Aquinas juga membagi kekuasaan negara dan gereja di mana pada saat itu kekuasaan dua wilayah ini cenderung bercampur. Menurutnya baik gereja maupun negara mempunyai wilayah masing-masing. Negara mengatur lingkungan duniawi/alamiah

\footnotetext{
${ }^{7}$ Hall, Calvin di Ranah Publik, 8.

${ }^{8}$ Willem Balke, "Pandangan Calvin Mengenai Gereja dan Negara" dalam Agustinus M. L. Batlajery dan Th. van den End, ed., Ecclesia Reformata Semper Reformanda: Dua Belas Tulisan Mengenai Calvin dan Calvinisme (Jakarta: BPK Gunung Mulia, 2014), 163.

${ }^{9}$ Willem Balke, "Pandangan Calvin Mengenai Gereja dan Negara", 163.

${ }^{10}$ Hall, Calvin di Ranah Publik, 22.
} 
sedangkan gereja mengatur lingkungan rohani/supra-alamiah. ${ }^{11}$ Konsep ini kemudian juga diteruskan oleh John Calvin.

\section{CALVIN DAN CALVINISME}

Bagaimana pandangan Calvinis tentang negara? Apakah sebuah negara atau pemerintah terbentuk akibat dosa? Dalam hal ini, Calvinis tidak mengikuti pandangan Augustinus tetapi Aquinas. Bagi orang Calvinis, negara adalah sebuah organisasi yang terbentuk secara alami karena dorongan sosial, sozial-trek, yang ditempatkan Tuhan di dalam diri manusia. Ketika sekelompok manusia berdiam di sebuah wilayah maka untuk mencapai tujuan bersama mereka membutuhkan mekanisme dari pemerintahan. ${ }^{12}$ Seandainya manusia tidak jatuh dalam dosa, negara tetap ada dan negara itu adalah negara yang sempurna yaitu kerajaan Allah. ${ }^{13}$

Salah satu contoh yang dapat diberikan untuk membuktikan bahwa pemerintahan tetap ada walaupun dunia tidak berdosa adalah kondisi malaikat yang tidak berdosa. Alkitab mencatat bahwa ada penghulu malaikat (1 Tesalonika 4:16) yaitu Mikhael

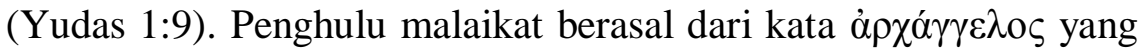

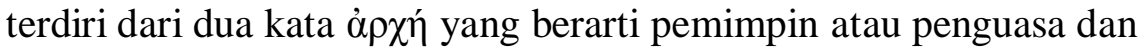

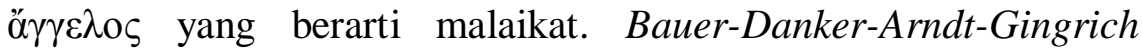
Greek Lexicon of the New Testament mendefinisikan penghulu malaikat sebagai berikut a member of the higher ranks in the celestial hierarchy, chief angel, archangel. ${ }^{14}$ Hal ini berarti malaikat mempunyai pemimpin dan ada struktur pemerintahan di mana penghulu malaikat memerintah atas malaikat-malaikat lain yang tidak berdosa.

\footnotetext{
${ }^{11}$ Willem Balke, "Pandangan Calvin Mengenai Gereja dan Negara", 163.

${ }^{12}$ H. Henry Meeter, Pandangan-Pandangan Dasar Calvinisme (Surabaya: Penerbit Momentum, 2012), 99.

${ }^{13}$ Ibid., 100.

${ }^{14}$ William Arndt et al., A Greek-English Lexicon of the New Testament and Other Early Christian Literature (Chicago: University of Chicago Press, 2000), 137.
} 
Bukti kedua yang membuktikan bahwa tanpa dosa tetap ada pemerintahan adalah teks Matius 19:28, yaitu perkataan Yesus kepada kedua belas murid-Nya, "Aku berkata kepadamu, sesungguhnya pada waktu penciptaan kembali, apabila Anak Manusia bersemayam di tahta kemuliaan-Nya, kamu, yang telah mengikut Aku, akan duduk juga di atas dua belas takhta untuk menghakimi kedua belas suku Israel." Ayat ini menyatakan bahwa nanti setelah langit dan bumi baru, setelah dosa dihapus dari dunia ini maka tetap ada pemerintahan di mana kedua belas murid Tuhan Yesus akan menjadi penguasa atas orang-orang lain.

Bukti yang selanjutnya adalah dari Lukas 19:12-27. Di dalam teks ini Tuhan Yesus mengatakan bahwa pada akhirnya yang menghasilkan sepuluh mina akan "menerima kekuasaan atas sepuluh kota" dan yang menghasilkan lima mina akan "menguasai lima kota". Sekali lagi teks ini berpadanan dengan Matius 19:28 di mana pada akhir zaman, di mana tidak ada dosa, ada orang-orang yang ditempatkan Tuhan sebagai penguasa atau pemerintah.

Kalau memang pemerintahan atau negara bukan akibat dosa lalu kira-kira apa fungsi negara dalam dunia tanpa dosa? Ketika semua manusia tanpa dosa maka semua orang akan mengetahui dan melakukan hal-hal yang benar, jadi tidak perlu ada orang yang membuat dan menegakkan hukum, namun manusia memiliki mandat budaya yang Tuhan percayakan kepada manusia. Di dalam menjalankan mandat budaya maka manusia akan mengadakan kegiatan-kegiatan berkelompok yang membutuhkan pemimpin bagi kelompok tersebut. Walaupun manusia sempurna namun kemauan individual harus dipersatukan oleh pemimpin agar menjadi 
kesatuan kemauan dan tujuan. Tanpa adanya kesatuan kemauan dan tujuan maka tugas kelompok tidak dapat tercapai. ${ }^{15}$

Sejak manusia berdosa maka fungsi negara dalam dunia yang berdosa adalah fungsi yang telah disebut di atas ditambah dengan fungsi untuk menghukum para pelanggar hukum. Sekarang dibutuhkan pengadilan dan kepolisian untuk menerapkan hukum. Roma 13:1-4 menegaskan bahwa pemerintah diberikan otoritas dari Tuhan "untuk membalaskan murka Allah atas mereka yang berbuat jahat". Pemerintah adalah anugerah umum Tuhan untuk membatasi kejahatan. ${ }^{16}$

Apakah bentuk negara terbaik? Calvinisme tidak mendukung baik itu monarki, aristokrasi, demokrasi, atau bentuk pemerintah apa pun. John Calvin juga tidak menghendaki theokrasi karena theokrasi Musa hanya diperuntukan bagi bangsa Israel dan bukan bangsa lain. Tuhan sanggup memakai bentuk pemerintah apa pun untuk memerintah manusia. Di satu daerah mungkin cocok demokrasi, di negara bagian lain mungkin monarki. Pemerintahan yang baik bukan ditentukan dari bentuknya (monarki, aristokrasi, atau demokrasi) tetapi pada karakter moral dan spiritual dari rakyatnya karena setiap bentuk pemerintahan ada sisi positif dan negatifnya. ${ }^{17}$

Ada lima hal yang merupakan ciri khas pemerintahan Calvinistik, yaitu: ${ }^{18}$

1. Calvinisme menentang adanya satu negara yang mencakup seluruh dunia atau negara-negara yang terlalu besar, alasannya karena Tuhan menggagalkan usaha manusia

\footnotetext{
${ }^{15}$ Meeter, Pandangan-Pandangan Dasar Calvinisme, 100-101.

${ }^{16}$ Ibid., 101-102.

${ }^{17}$ Ibid., 106-108.

${ }^{18}$ Ibid., 120-122.
} 
mendirikan satu kekaisaran dunia di menara Babel dan untuk menghindari pemusatan kekuatan diktatorial ke dalam tangan sedikit orang.

2. Calvinisme tidak menyetujui adanya pemusatan kekuasaan negara pada satu orang atau beberapa orang saja. Rakyat mempunyai hak untuk setuju atau tidak setuju atas kebijakan pemerintah melalui pemungutan suara atau pengungkapan opini publik.

3. Hak-hak rakyat tidak boleh diabaikan oleh penguasa.

4. Supaya tidak terjadi pemusatan kekuasaan pada beberapa orang maka harus ada lembaga legislatif, eksekutif, dan yudikatif, yang tidak dikuasai oleh orang-orang yang sama.

5. Setiap lembaga sosial punya kedaulatan wilayahnya sendiri, misalnya rumah tangga, sekolah, gereja, atau organisasi sosial lainnya. Masing-masing organisasi-organisasi mempunyai tugas dari Tuhan dan eksistensinya tidak tergantung pada negara. Masing-masing organisasi berdaulat atas wilayahnya sendiri. Konsep ini dikenal dengan nama sphere sovereignity.

Kaum Calvinis mengatakan ada dua tugas utama dari pemerintah, yaitu untuk melaksanakan atau menegakkan keadilan dan yang kedua adalah untuk meningkatkan kesejahteraan umum negara dan warganya. Penegakkan keadilan adalah pelaksanaan dari Roma 13:1-4. Pemerintah juga berkewajiban membangun kesejahteraan material, kultural, dan kemanusiaan warganya. Pemerintah wajib memberikan bantuan kepada organisasiorganisasi industrial, sosial, atau intelektual masyarakat di saat-saat kritis atau bencana melalui subsidi atau menerbitkan peraturan. ${ }^{19}$

John Calvin mengatakan bahwa rakyat harus setia kepada pemerintah dan harus menghormati jabatan tersebut. Perintah-

${ }^{19}$ Meeter, Pandangan-Pandangan Dasar Calvinisme, 127, 135. 
perintah dari penguasa tidak boleh dilawan sebab perlawanan terhadap pemerintah sama dengan perlawanan terhadap Allah. Walaupun pemerintah tidak baik, rakyat tetap harus setia karena pejabat pemerintah yang tidak adil dan sewenang-wenang dibangkitkan oleh Tuhan untuk menghukum dosa umat-Nya. Orang Kristen harus menaati penguasa walaupun mereka adalah orang tidak beriman dan memusuhi Allah. ${ }^{20}$

Apakah orang Kristen boleh memberontak terhadap pemerintah? Dalam hal ini John Calvin senada dengan Thomas Aquinas. John Calvin sangat berhati-hati dalam hal ini. John Calvin mengatakan, pertama, tidak boleh sembarangan orang mengadakan perlawanan terhadap pemerintah. Yang berhak untuk melawan keputusan penguasa adalah para bawahan mereka atau penguasa yang lebih rendah. Menurut Calvin, seorang penguasa yang melanggar batas-batas wewenangnya maka ia bukan lagi penguasa yang sah. Calvin memberikan contoh tokoh Daniel, di mana menurutnya Daniel tidak berdosa terhadap raja ketika Ia berdoa kepada Tuhan walau melanggar perintah Raja Darius (Daniel 6). Kedua, John Calvin menolak pemberontakan bersenjata. Walaupun orang Protestan Perancis dianiaya oleh pihak Gereja Katolik dan pemerintah Perancis namun Calvin menasehati orang Protestan Perancis untuk tidak mengangkat senjata untuk menghentikan penganiayaan. $^{21}$

Di dalam tafsiran John Calvin tentang ucapan Petrus dalam Kisah Para Rasul 4:19, John Calvin menulis sebagai berikut, "Therefore, by what title soever men be called, yet must we hear them only upon this condition, if they lead us not away from obeying God". 22 Calvin mengatakan bahwa kita harus mematuhi

\footnotetext{
${ }^{20}$ Balke, "Pandangan Calvin Mengenai Gereja dan Negara", 172-173.

${ }^{21}$ Ibid., 174.

${ }^{22}$ John Calvin dan Henry Beveridge, Commentary Upon the Acts of the Apostles, vol. 1 (Bellingham, WA: Logos Bible Software, 2010), 178.
} 
pemerintah dengan syarat selama pemerintah tidak membuat kita menyimpang dari ketaatan kepada Allah. Hal yang sama juga dikemukakan dalam tafsiran Kisah Para Rasul 5:29,

"This is the sum of their answer, It is lawful for them, nay, they ought to prefer God before men. God commandeth us to bear witness of Christ; therefore it is in vain for you to command us to keep silence. But I have declared before, in the third chapter, when this sentence taketh place, that we ought rather to obey God than men. God doth set men over us in such sort with power, that he keepeth still his own authority safe and sound. Therefore, we must obey rulers so far, that the commandment of God be not broken.",23

\section{Di dalam tafsiran Kisah Para Rasul 17:7, John Calvin menulis:}

"but if at any time religion enforce us to resist tyrannical edicts and commandments which forbid us to give due honour to Christ, and due worship to God; we may then justly say for ourselves, that we are not rebellious against kings, for they be not so exalted, that they may go about like giants to pull God out of his seat and throne.

Calvin mengatakan bahwa kita tidak melawan raja, tetapi kita melawan perintah raja yang melarang kita untuk memuliakan Kristus dan menyembah Tuhan. Itulah sebabnya di dalam tafsiran Kitab Daniel 6:10, John Calvin mengatakan,

"Daniel's open profession of his faith in God has been censured as too bold and ill judged for our imitation, but it has also been ably vindicated as an example of perseverance in religious duty when

\footnotetext{
$1,214$.

${ }^{24}$ John Calvin dan Henry Beveridge, Commentary Upon the Acts of the Apostles, vol. 2 (Bellingham, WA: Logos Bible Software, 2010), 138.
}

${ }^{23}$ John Calvin dan Henry Beveridge, Commentary Upon the Acts of the Apostles, vol. 
our conscience justifies us in maintaining God's truth before man". 25

\section{SIMPULAN}

John Calvin berpendapat bahwa pemerintah ada bukan karena akibat dosa seperti yang dikemukakan oleh Abraham Kuyper maupun Augustinus. Karena manusia adalah makhluk sosial maka hal itu mendorong terjadinya pemerintahan yang bertujuan untuk mencapai tujuan bersama. Ada pula bukti-bukti dari Alkitab, seperti 1 Tesalonika 4:16; Yudas 1:9; Matius 19:28; dan Lukas 19:12-27 yang menggambarkan adanya pemerintahan di dalam kumpulan masyarakat atau malaikat yang tidak berdosa.

Fungsi pemerintah dalam dunia yang tidak berdosa adalah untuk mempersatukan kemauan dan tujuan, tetapi sejak manusia jatuh ke dalam dosa, fungsi pemerintah ditambah dengan fungsi untuk menghukum. Dua tugas utama pemerintah adalah untuk menegakkan keadilan dan meningkatkan kesejahteraan umum negara dan rakyatnya.

Mengenai relasi antara pemerintah dan orang Kristen, John Calvin mengatakan bahwa orang Kristen harus setia kepada pemerintah walaupun pemerintah tidak baik, karena semua penguasa dibangkitkan oleh Tuhan. Namun hal itu tidak berarti orang Kristen harus selalu patuh. Jika pemerintah membuat orang Kristen menyimpang dari ketaatan akan Allah, melarang orang Kristen untuk memuliakan Kristus dan menyembah Tuhan, maka orang Kristen boleh tidak taat kepada pemerintah. Kudeta terhadap penguasa yang lalim hanya boleh dilakukan oleh para bawahan penguasa untuk mencegah terjadinya kekosongan kekuasaan namun dalam hal ini John Calvin sangat berhati-hati. John Calvin

\footnotetext{
${ }^{25}$ John Calvin, Commentary on the Book of The Prophet Daniel, vol. 1 (Grand Rapids, Michigan, Baker Book House: 2005), 462.
} 
selalu berusaha mengambil jalan tengah di dalam membicarakan relasi antara pemerintah dan orang Kristen.

\section{DAFTAR RUJUKAN}

Arndt, William et al. A Greek-English Lexicon of the New Testament and Other Early Christian Literature. Chicago: University of Chicago Press, 2000.

Balke, Willem. "Pandangan Calvin Mengenai Gereja dan Negara" dalam Agustinus M. L. Batlajery dan Th. van den End, ed., Ecclesia Reformata Semper Reformanda: Dua Belas Tulisan Mengenai Calvin dan Calvinisme. Jakarta: BPK Gunung Mulia, 2014.

Calvin, John dan Henry Beveridge. Commentary Upon the Acts of the Apostles, vol. 1. Bellingham, WA: Logos Bible Software, 2010.

Calvin, John dan Henry Beveridge. Commentary Upon the Acts of the Apostles, vol. 2. Bellingham, WA: Logos Bible Software, 2010.

Calvin, John. Commentary on the Book of The Prophet Daniel, vol. 1. Grand Rapids, Michigan, Baker Book House: 2005.

Hall, David W. Calvin di Ranah Publik. Surabaya: Penerbit Momentum, 2011.

Kuyper, Abraham. Ceramah-Ceramah Mengenai Calvinisme. Surabaya: Penerbit Momentum, 2005.

Meeter, H. Henry. Pandangan-Pandangan Dasar Calvinisme. Surabaya: Penerbit Momentum, 2012. 